\title{
ANALISA DAMPAK PENGGUNAAN FILTER L-C-L TERHADAP KINERJA PENGATUR KECEPATAN MOTOR INDUKSI
}

\author{
M.Fawwaz Rizaldy ${ }^{1}$, Khairudin ${ }^{2}$, Noer Soedjarwanto ${ }^{3}$, Nining Purwasih ${ }^{4}$ \\ 1,2,3,4 Jurusan Teknik Elektro, Universitas Lampung; Jl. Prof. Sumantri Brojonegoro No.1, Bandar \\ Lampung
}

Received: 12 November 2021

Accepted: 23 Desember 2021

Published: 10 Januari 2022

Keywords:

Diode clamped multilevel inverter, Harmonisa, Filter, Pengaturan kecepatan.

\section{Corespondent Email:}

fawwazrizaldy@gmail.com

\begin{abstract}
Abstrak. Pengaturan kecepatan motor dilakukan dengan mengubah tegangan input, ataupun frekuensi yang terdapat pada motor. Maka hal yang lebih mungkin dilakukan adalah dengan mengubah kecepatan motor dengan mengubah frekuensi pada sumber stator. Inverter bisa digunakan sebagai pengontrol yang dapat mengatur kecepatan pada motor induksi, topologi inverter yang digunakan adalah diode clamped multilevel inverter tetapi inverter masih mengandung harmonisa yang cukup tinggi, sehingga inverter memerlukan filter untuk mengurangi besarnya harmonisa. Filter yang digunakan adalah filter pasif L-C-L, Kapasitas atau ukuran dari filter yang dibutuhkan akan semakin besar berbanding lurus dengan besar daya yang digunakan.
\end{abstract}

How to cite this article:

Fawwas (2022). Analisa Dampak Penggunaan Filter $L-C$ - $L$ Terhadap Kinerja Pengatur Kecepatan Motor Induksi. Jurnal Informatika dan Teknik Elektro Terapan, 10(1)

\begin{abstract}
Motor speed controller is done by changing the input voltage, or frequency contained in the motor. So what is more likely to be done is to change the motor speed by changing the frequency at the stator source. The inverter can be used as a controller that can adjust the speed of the induction motor, the inverter topology used is a diode clamped multilevel inverter but the inverter still contains high enough harmonics, so the inverter requires a filter to reduce the amount of harmonics. The filter used is a passive L-C-L filter, the capacity or size of the filter required will be greater in direct proportion to the amount of power used.
\end{abstract}




\section{PENDAHULUAN}

Perkembangan teknologi dari tahun ke tahun semakin pesat sehingga memberikan perubahan yang besar terhadap kehidupan masyarakat baik dalam segala bidang terutama pada bidang industri. Salah satu alat yang sering digunakan pada bidang industri adalah motor induksi. Motor induksi merupakan alat yang bermanfaat, tetapi masih terdapat kekurangan pada motor induksi yaitu terutama dalam hal pengaturan kecepatannya. Secara aplikasinya kecepatan motor induksi dapat diatur dengan mengubah tegangan input, ataupun frekuensi yang terdapat pada motor. Maka hal yang lebih mungkin dilakukan adalah dengan mengubah kecepatan motor dengan mengubah frekuensi pada sumber stator[2].

Inverter merupakan alat yang dapat mengubah arus searah menjadi bolak - balik. Selain itu, inverter juga dapat digunakan untuk mengubah frekuensi yang terdapat pada tegangan outputnya. Maka dari itu inverter bisa digunakan sebagai pengontrol yang dapat mengatur perubahan pada motor induksi. Akan tetapi, inverter masih mengandung harmonisa yang cukup tinggi, sehingga inverter memerlukan filter untuk mengurangi besarnya harmonisa tegangan [6][8]. Kapasitas atau ukuran dari filter yang dibutuhkan akan semakin besar berbanding lurus dengan besar daya yang digunakan. untuk mengatasi kendala tersebut dibuat multilevel inverter jenis DCMI (diode clamped multilevel inverter). DCMI adalah tipe inverter yang besar harmonisa tegangannya dapat dikurangi dengan menambah tingkatan pada inverter. Sehingga bisa didapatkan inverter dengan nilai harmonisa yang kecil meski tidak menggunakan filter

\section{TINJAUAN PUSTAKA}

\section{A. Diode Clamped Multilevel Inverter (DCMI)}

Penelitian sebelumnya telah dilakukan tahun 2019 dengan judul Pengaturan Kecepatan Motor Induksi Menggunakan Multilevel Inverter dengan Mengatur Frekuensi no ISSN 2581 - 0049. Topologi multilevel inverter yang digunakan adalah diode clamped multi level inverter. DCMI merupakan salah satu dari jenis multilevel inverter yang cara penggunaannya menggunakan prinsip pembagi tegangan pada sumber tegangan dc dengan variasi topologi inverter yang menghasilkan gelombang keluaran yang menyerupai gelombang sinusoidal. Rangkaian DCMI dapat dilihat pada gambar 1.

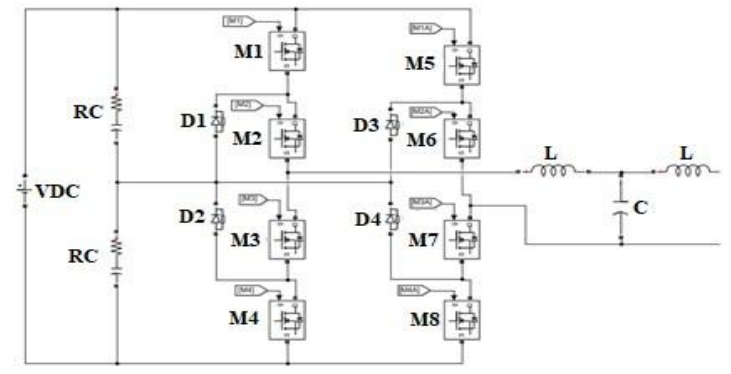

Gbr. 1 Rangkaian Diode Clamped Multilevel Inverter
Topologi DCMI ini menggunakan satu sumber tegangan DC sebagai supply, kapasitor berfungsi sebagai pembagi tegangan yang diberikan dari sumber tegangan DC, mosfet yang berfungsi sebagai media pensaklaran untuk DCMI ini, dioda yang berfungsi membatasi tegangan yang masuk ke komponen mosfet, dan resistor sebagai beban yang ada pada rangkaian DCMI [4].

Prinsip kerja DCMI ini menyerupai prinsip kerja inverter full bridge, dimana masing - masing komponen mosfet berpasangan dengan komponen mosfet lainnya [9]. Prinsip kerja inverter ini dicontohkan menggunakan topologi diode clamped multilevel inverter satu fasa yang memiliki gelombang output 5 tingkatan.

\section{B. Gate Driver}

Gate driver merupakan suatu rangkaian elektronika yang berperan sebagai gerbang pemisah antara driver daya dengan microcontroller. Gate driver berfungsi sebagai penguat tegangan pada microcontroller yang pada umumnya sebesar $5 \mathrm{~V}$ kemudian akan menjadi tegangan yang memicu gate pada saklar daya (MOSFET) sesuai dengan datasheet yang digunakan. Pada gate driver sendiri menggunakan ic dengan tipe HCPL, yaitu dengan menggunakan optocoupler. Optocoupler akan bekerja berdasarkan cahaya optic, dimana terdapat bagian utama dari optocoupler yaitu transmitter yang akan berfungsi sebagai pengirim cahaya optic dan receiver yang berfungsi sebagai pendeteksi sumber cahaya. Masing-masing bagian optocoupler (Transmitter dan receiver) tidak memiliki hubungan konduktif rangkaian secara langsung tetapi dibuat dalam satu kemasan. Berikut rangkaian terpadu pada IC HCPL, yang dapat dilihat pada gambar 2 .

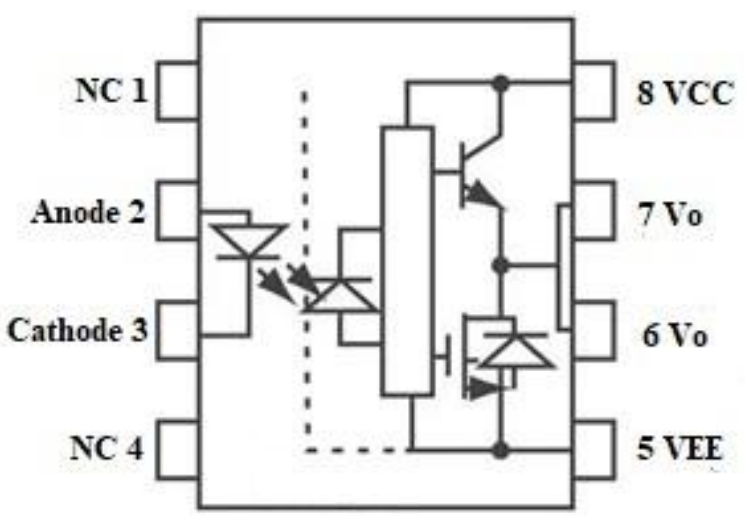

Gbr. 2 Rangkaian IC HCPL 3120

\section{Harmonisa}

Harmonisa dapat didefinisikan sebagai berikut yaitu cacat gelombang sinus yang terjadi diakibatkan oleh interaksi antara bentuk gelombang sinus sistem dengan gelombang lain yang mempunyai frekuensi kelipatan bilangan bulat dari frekuensi inti atau fundamentalnya. Gelombang lain tersebut menumpang pada gelombang 
aslinya sehingga mengakibatkan bentuk gelombang cacat yang merupakan jumlah antara gelombang asli dengan gelombang harmoniknya [10]. Harmonisa ke 3 merupakan harmonisa yang paling berpengaruh dalam bentuk gelombang sinusoidal harmonisa ke 3 yang sangat besar menyebabkan bentuk gelombang sinusoidal menjadi bentuk gelombang gergaji sehingga gelombang tersebut dapat disebut sebagai gelombang rusak dan sangat tidak aman bagi alat elektronika sehingga dapat merusak alat tersebut. Berikut adalah gambar gelombang fundamental dan harmonisa ketiga dapat dilihat pada gambar 3.

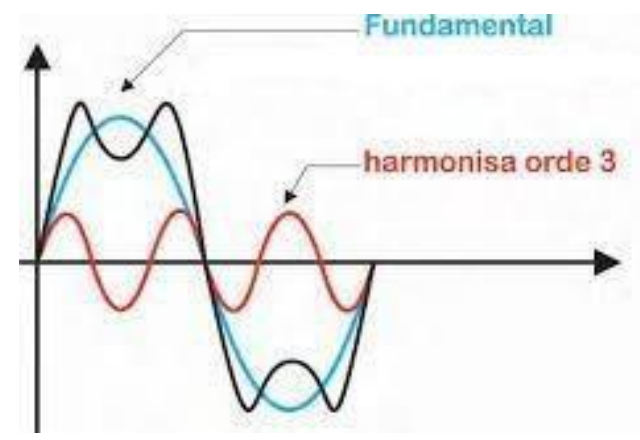

Gbr. 3 Fundamental dan Harmonisa ke-3

\section{Arduino Mega 2560}

Mikrokontroler yang dipakai pada penelitian ini adalah arduino mega 2560. Arduino mega 2560 memiliki dimensi ukuran $10 \times 5(\mathrm{~cm})$ dan biasa digunakan untuk menjalankan system yang lebih kompleks dan membutuhkan pin digital yang banyak berikut adalah spesifikasi teknis arduino 2560 [3].

- IC ATmega2560

- Pin Digital 54 buah dengan 15 pin PWM

- Pin analog 16

- Pin UART 4

- Oscilator Crystal 16Mhz

- Tombol reset

- Port USB

- Power jack

- ICSP header

- Flash memory 256KB

- SRAM 8KB

- EEPROM $4 \mathrm{~KB}$

Gambar arduino mega 2560 dapat dilihat pada gambar 4.

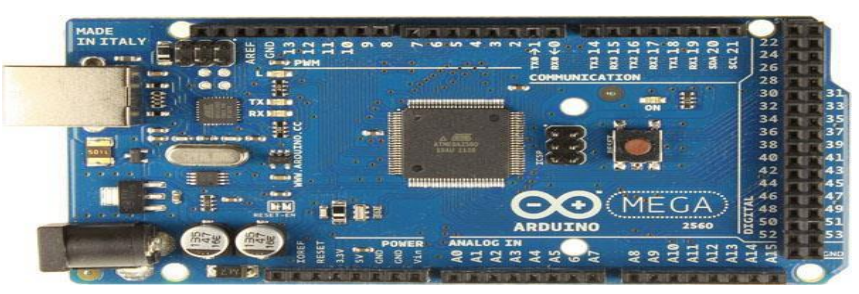

Gbr. 4 Arduino Mega 2560

\section{METODE PENELITIAN}

\section{A. Alat dan Bahan}

Alat dan bahan yang digunakan pada penelitian ini dibagi menjadi perangkat keras (hardware) dan perangkat lunak (software) dengan rincian sebagai berikut.

Perangkat keras yang digunakan :

1. Rangkaian catu daya (power supply)

2. Motor Kapasitor Tipe 73134 Class 0.1

3. Rangkaian diode clamped multilevel inverter

4. (DCMI) 3 Tingkat satu fasa

5. Rangkaian gate driver mosfet

6. Arduino Mega 2560

7. Laptop ACER E5-475G-58WK

8. Osiloskop digital

9. Komponen indukor dan kapasitor untuk filter LC-L

10.

Perangkat lunak yang digunakan, yaitu:

1. Matlab

2. Diptrace 2.3

3. Microsoft Office 2013

4. Arduino IDE

\section{B. Diagram Alir Penelitian}

Penyelesaian tugas akhir dilakukan dalam beberapa tahap, secara umum tahap tahap tersebut dijelaskan pada gambar 5.

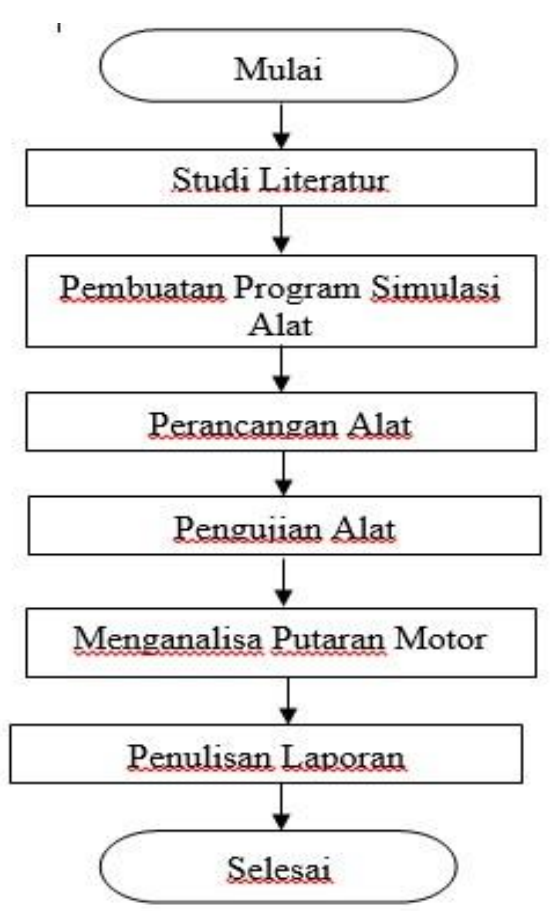

Gbr. 5 Diagram Alir Penelitian 


\section{Diagram Blok}

Bagian bagian pengatur motor induksi terdiri dari sumber DC, multi level inverter, gate driver, arduino, Filter L-C-L, dan motor induksi 1 fasa. Ketika arduino memberikan trigger ke rangkaian gate driver yang kemudian ke rangkaian inverter, maka inverter akan melakukan pengaturan dengan mengubah nilai frekuensi. Tegangan satu fasa yang dihasilkan inverter akan masuk ke filter yang kemudian akan ke beban motor. Lalu pengaturan kecepatan motor akan dilakukan berdasarkan frekuensi yang dapat diubah-ubah yang diberikan oleh inverter. Diagram blok perancangan alat dapat dilihat pada gambar 6.

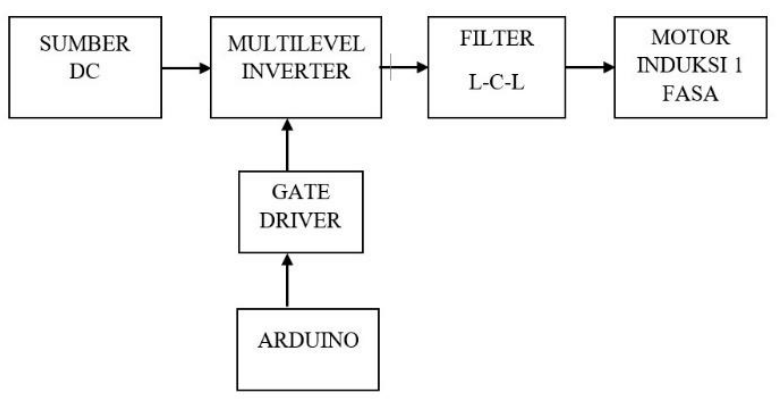

Gbr. 6 Diagram Blok Penelitian

\section{Filter $L-C-L$}

Filter L-C-L dibuat untuk menekan harmonisa yang dihasilkan oleh multilevel inverter agar sesuai dengan standar internasional [5]. Dalam rangkain filter LCL terdiri dari inductor 2 buah dan juga kapasitor berikut adalah rinciannya.

- Inductor $7 \mathrm{mH} 2$ buah

- Kapasitor 130uF 1 buah

Penentuan komponen tersebut berdasarkan perhitungan yang akan dijabarkan di Bawah ini :

1. Menentukan PF (faktor daya) awal dan faktor daya yang diinginkan :

PF awal

$$
=0.85
$$

PF yang diinginkan

$$
=0.98
$$

Faktor pengali berdasarkan table cos phi $=$ 0.361

2. Menentukan daya reaktif

$\mathrm{Q} \quad=90 \times 0.361$

$\mathrm{Q} \quad=32.49 \mathrm{VAR}$
3. Menentukan frekuensi tunning, untuk faktor safety filter di tunning 5\% dibawah orde asli : $n-\left(5 \% X^{3}\right)$

$$
3-(5 \% \times 3)=2.85
$$

4. Menentukan nilai kapasitor

$$
\begin{aligned}
& X c=\frac{30^{2}}{32.49}=\frac{900}{32.49}=27.7 \Omega \\
& C=\frac{1}{2 \times 3.14 \times 50 \times 27.7}=114 \times 10^{-6} \mathrm{~F}
\end{aligned}
$$

Dikarenakan komponen kapasitor dipasaran tidak memungkinkan untuk mencari dengan kapasitas $114 \mathrm{uF}$ maka digunakan kapasitor dengan kapasitas 130uF.

5. Menentukan nilai inductor

$$
\begin{aligned}
& X_{L}=\frac{16.2}{2.85^{2}}=1.995^{\prime} \Omega \\
& L=\frac{1.995}{2 \times 3.14 \times 50}=\frac{1.995}{314}=6.35 \times 10^{-3} \mathrm{H}=
\end{aligned}
$$

\section{$6.35 \mathrm{mH}$}

Dikarenakan komponen inductor dipasaran tidak memungkinkan untuk mencari kapasitas $6.35 \mathrm{mH}$ maka digunakan inductor dengan kapasitas $7 \mathrm{mH}$. Hasil perancangan filter dapat dilihat pada gambar 7

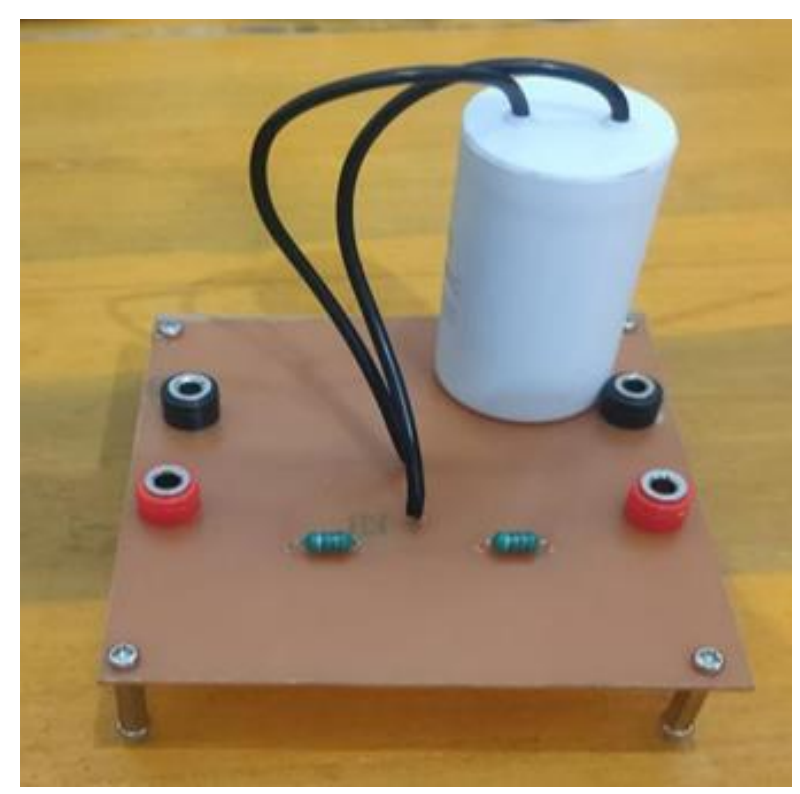

Gbr. 7 Hasil Perancangan Filter L-C-L 


\section{HASIL DAN PEMBAHASAN}

\section{A. Pengujian THD (total harmonic distortion)}

pada pengujian THD menunjukan bentuk gelombang dan THD (Total Harmonic Distortion) yang dihasilkan ketika menggunakan atau tidak menggunakan filter L-CL. THD dan bentuk gelombang dapat dilihat pada gambar 8 dan gambar 9 .

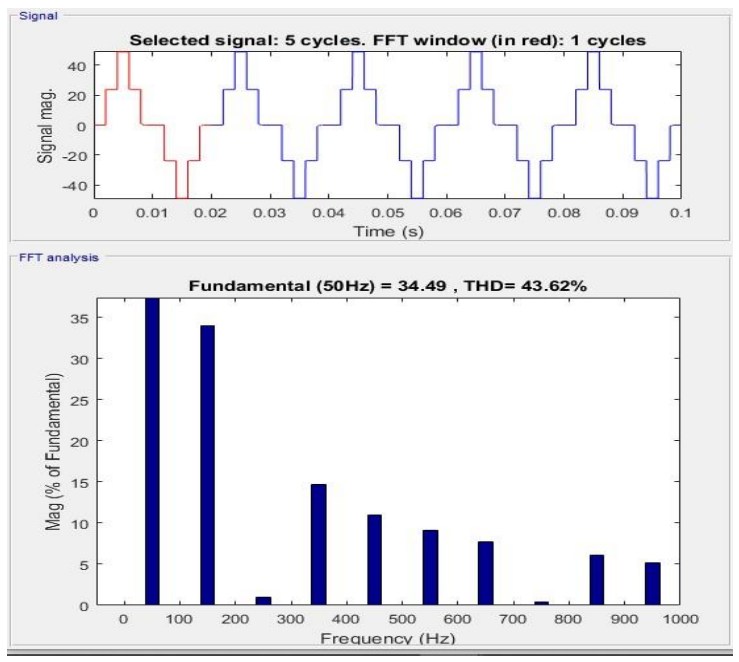

Gbr. 8 Bentuk Gelombang Keluaran dan Nilai THD Tanpa Menggunakan Filter

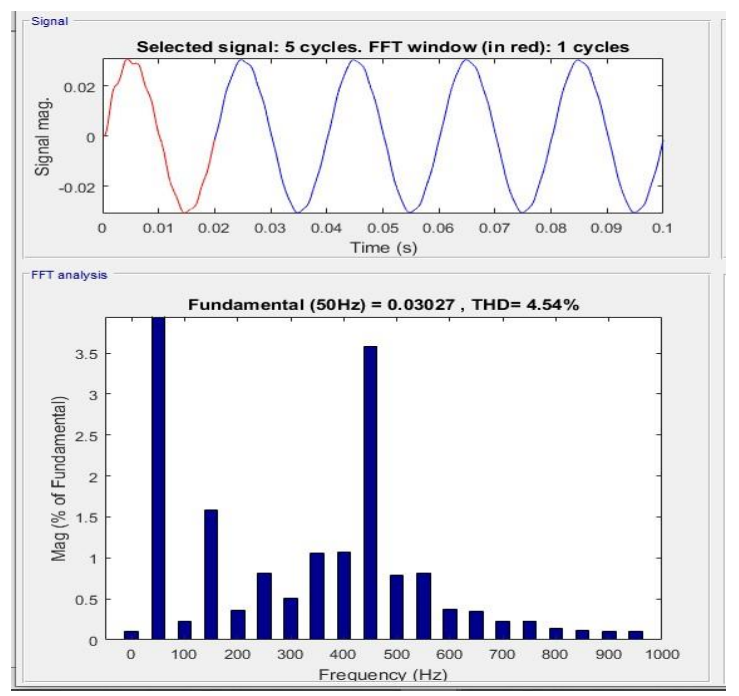

Gbr. 9 Bentuk Gelombang Keluaran dan Nilai THD Saat Menggunakan Filter

Hasil pengujian THD menunjukan bahwa gelombang yang dihasilkan setelah menggunakan filter LCL lebih sinusoidal dibandingkan tanpa menggunakan filter LCL, nilai THD mengalami reduksi setelah menggunakan filter sebesar $89.59 \%$. sehingga besar harmonisa telah sesuai standar IEEE 519-1992 mengenai application of harmonic limit.

\section{B. Pengujian Multilevel Inverter}

Pengujian dilakukan untuk melihat gelombang dan tegangan output yang dihasilkan. Pengambilan data menggunakan osiloskop dan multimeter.

1. Pengujian tanpa filter LCL

Input frekuensi yang digunakan adalah $50 \mathrm{~Hz}$ dan input tegangan DC yang digunakan adalah sebesar 30VDC. Hasil gelombang dan tegangan dapat dilihat pada gambar 11 dan gambar 12.

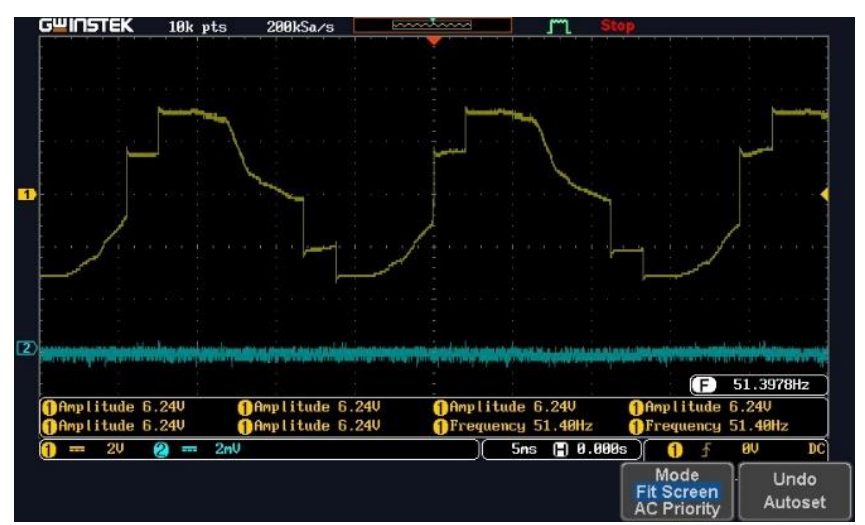

Gbr. 10 Gelombang Keluaran Tanpa Filter LCL

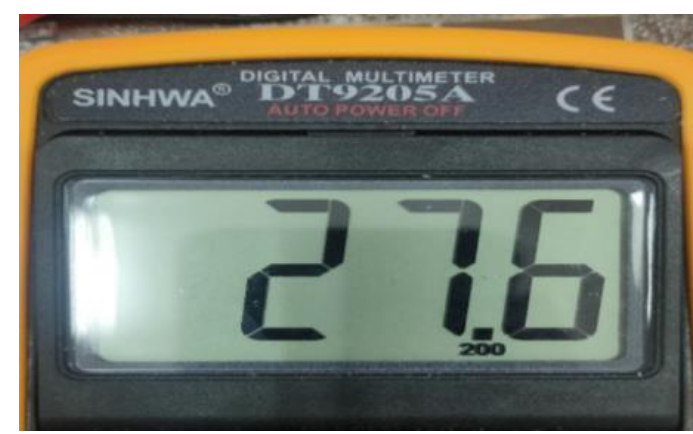

Gbr. 11 Tegangan Keluaran Tanpa Filter LCL

2. Pengujian menggunakan filter LCL

Pengujian menggunakan input yang sama dengan tanpa filter yaitu frekuensi $50 \mathrm{~Hz}$ dan tegangan 30VDC. Hasil gelombang dan tegangan dapat dilihat pada gambar 12 dan gambar 13.

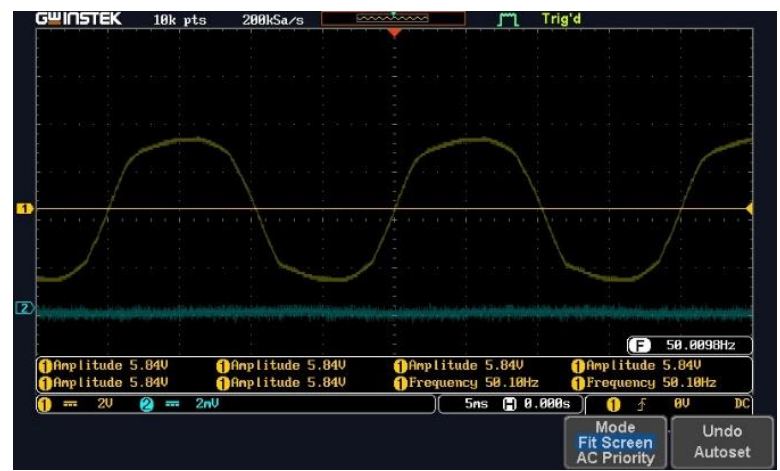

Gbr. 12 Gelombang Keluaran Menggunakan Filter LCL 


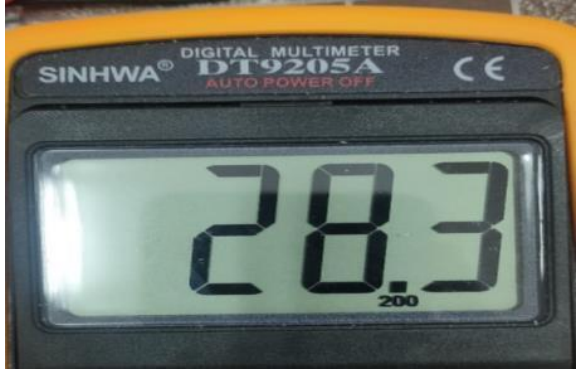

Gbr. 13 Tegangan Keluaran Menggunakan Filter LCL

\section{Perbandingan Gelombang Output}

Perbandingan gelombang keluaran antara menggunakan filter dan tanpa menggunakan filter selisih antara dua gelombang tersebut merupakan noise yang dihasilkan. Proses pengambilan data menggunakan osiloskop yang kemudian disave dengan format CSV yang kemudian kedua gelombang tersebut digabungkan menggunakan excel untuk melihat perbandingannya. Berikut adalah perbandingan gelombang yang ditunjukan oleh gambar 14.

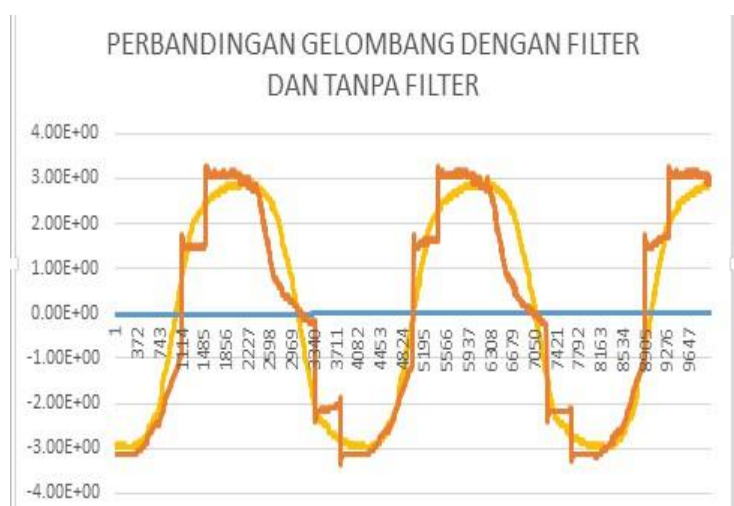

Gbr. 14 Perbandingan Gelombang Dengan Filter dan Tanpa Filter

\section{Pengujian Kecepatan Motor}

Kecepatan motor didapatkan melalui proses pengujian dengan menggunakan sensor kecepatan FC-03 IR, kemudian hasil pembacaan sensor akan ditampilkan pada serial monitor untuk melihat kecepatan yang dihasilkan dari beberapa input frekuensi. Input frekuensi yang digunakan adalah $40 \mathrm{~Hz}$ sampai dengan $60 \mathrm{~Hz}$ dengan selisih setiap pengujian sebesar $2 \mathrm{~Hz}$. Berikut adalah gambar proses pengujian kecepatan dan tabel dari kecepatan yang dihasilkan yang ditunjukan pada gambar 15 dan table 1 .

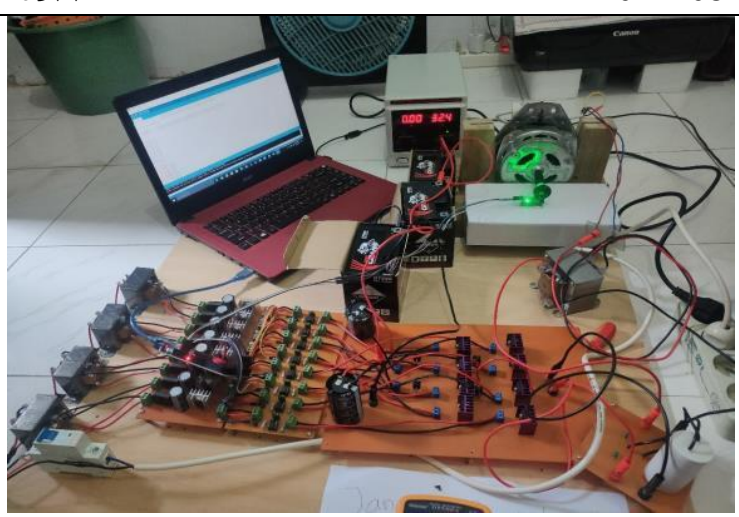

Gbr. 15 Proses Pengujian Kecepatan

Tabel. 1 Data Hasil Kecepatan Motor

\begin{tabular}{|c|c|c|c|}
\hline \multirow[b]{2}{*}{ No } & \multirow[b]{2}{*}{$\begin{array}{c}\text { Frekuensi } \\
(\mathrm{Hz})\end{array}$} & \multicolumn{2}{|c|}{ Kondisi } \\
\hline & & $\begin{array}{c}\text { Kecepatan Tanpa } \\
\text { Filter } \\
\text { (RPM) }\end{array}$ & $\begin{array}{c}\text { Kecepatan Dengan } \\
\text { Filter } \\
\text { (RPM) }\end{array}$ \\
\hline 1 & 40 & 1104 & 1116 \\
\hline 2 & 42 & 1164 & 1170 \\
\hline 3 & 44 & 1200 & 1206 \\
\hline 4 & 46 & 1260 & 1266 \\
\hline 5 & 48 & 1320 & 1326 \\
\hline 6 & 50 & 1380 & 1386 \\
\hline 7 & 52 & 1440 & 1440 \\
\hline 8 & 54 & 1494 & 1494 \\
\hline 9 & 56 & 1548 & 1548 \\
\hline 10 & 58 & 1608 & 1608 \\
\hline 11 & 60 & 1656 & 1656 \\
\hline
\end{tabular}

\section{E. Analisis Kecepatan Motor}

Setelah melihat data hasil kecepatan motor AC 1 fasa dengan menggunakan filter dan tanpa menggunakan filter terdapat perbedaan dimana saat menggunakan filter kecepatan motor lebih cepat sedikit walau tidak signifikan saat dibawah frekuensi $50 \mathrm{~Hz}$ dibandingkan tanpa menggunakan filter. Dan ketika diatas frekuensi fundamental, putaran kecepatan motor menggunakan dan tanpa filter sama hal ini dikarenakan noise yang 
besar terjadi dibawah frekuensi $50 \mathrm{~Hz}$ diakibatkan proses switching mosfet, dan ketika diatas frekuensi fundamental noise terhalangi. Putaran motor lebih optimal saat frekuensi input pada arduino diatas frekuensi $50 \mathrm{~Hz}$. Pengaruh filter pada kecepatan motor tidak signifikan tetapi filter menekan harmonisa sehingga motor induksi memiliki rugi rugi yang minim dan dapat memperpanjang umur motor tersebut. Berikut adalah table perbandingan kecepatan motor saat menggunakan filter dan tanpa menggunakan filter.

\section{F. Manfaat Menggunakan Filter}

Filter pasif yang dirancang untuk menekan harmonisa. Sehingga total harmonic istortion menjadi rendah. Berdasarkan artikel [7] isebutkan beberapa pengaruh harmonisa tinggi.

A. Harmonisa Tinggi pada motor listrik :

- Rugi rugi pada stator sangat tinggi

- Rugi rugi rangkaian rotor sangat tinggi

- Laminasi stator dan rotor sehingga efisiensi menurun

- Panas pada rotor

- Mengurangi umur mesin

- Dapat menyebabkan terjadinya voltage zero crossing

\section{Click or tap here to enter text.}

\section{KESIMPULAN}

Pada percobaan yang dilakukan dapat dilihat bahwa THD yang dihasilkan dapat direduksi. Kecepatan motor yang dihasilkan ketika menggunakan filter dan tanpa menggunakan filter tidak ada perbedaan yang signifikan. Putaran kecepatan menggunakan filter dibawah frekuensi $50 \mathrm{~Hz}$ lebih besar dibanding tanpa filter. Putaran kecepatan diatas frekuensi $50 \mathrm{~Hz}$ antara menggunakan filter dan tanpa filter sama, terdapat perbedaan putaran kecepatan dikarenakan noise tetap yang dihasilkan dari proses switching mosfet berada dibawah frekuensi $50 \mathrm{~Hz}$ sehingga saat motor berputar diatas frekuensi $50 \mathrm{~Hz}$ dihasilkan putaran kecepatan yang sama

\section{DAFTAR PUSTAKA (REFERENCE)}

[1] D. D. Khaimar dan V. M. Deshmukh, "Performance Analysis of Diode Clamped 3 Level MOSFET Based Inverter," International Electrical Engineering Journal (IEEJ), vol. 5, No.7, pp. 1484-1489, 2014.

[2] D. W. Hart, Power Electronics, Valparaiso, Indiana: Mc Graw Hill, 2010

[3] Anonim, "Arduino Mega 2560 rev3", Arduino Store, [Online]. Available: https://store.arduino.cc/usa/mega-2560-r3. [Diakses 30 September 2020]

[4] N. Soedjarwanto, O. Zebua, M. H. Lazuardy, "Pengaturan Kecepatan Motor Induksi Menggunakan Multilevel Inverter Dengan Mengatur Frekuensi," Prosiding Seminar Nasional Teknologi Elektro Terapan, Vol. 03, ISSN: 2581-0049, 2019

[5] Y. Tang, P. C. Loh, P. Wang and F. H. Choo, "Generalized Design of High Performance Shunt Active Power Filter with Output LCL Filter," IEEE Transactions on Industrial Electronics, vol. 59, no. 3, pp. 1443-1452, 2012.

[6] A. Reznik, M. Simoes, A. Aldurra and S. Muyeen, "LCL Filter Design and Performance Analysis for Small Wind Turbine Systems," in IEEE Power Electronics and Machines in Wind Applications (PEMWA), pp.1-7, 2012

[7] Santoso, Surya, "Electrical power system quality", 2002.

[8] M. Liserre, F. Blaabjerg, S. Hansen, "Design and Control of an LCLFilter-Based ThreePhase Active Rectifier" in IEEE Trans. on Industry Applications, vol. 41, no. 5, 2005.

[9] Rohit G. Ramteke, Dr. U. V. Patil, "Comparative study of various PWM Techniques for Diode Clamped Multi-level Inverter (DCMLI)", International conference on Computer, Electrical \& Electronics Engg. (IETE-2013), Dr. Babasaheb Ambedkar Technological University, Lonere on 26th27th, Dec-2013.

[10] Kamran Jalili and Steffen Bernet, "Design of LCL Filters of ActiveFront-End Two-Level Voltage-Source Converters," IEEE Transactions on Industrial Electronics, vol. 56, no. 5, May 2009 